\title{
ASPEK BIOEKOLOGI SEBAGAI DASAR PENGELOLAAN SUMBERDAYA KEPITING BAKAU (Scylla Spp.) PADA EKOSISTEM MANGROVE PASSO
}

\author{
(Bioecological Aspects as Basic for Mud Crab (Scylla spp.) \\ Resource Management in Passo Ecosystem Mangroves)
}

\author{
Laura Siahainenia $^{1 *}$ dan Miftah Makatita $^{2}$ \\ ${ }^{1)}$ Jurusan Manajemen Sumberdaya Perairan Fakultas Perikanan dan Ilmu Kelautan Universitas Pattimura \\ ${ }^{2)}$ Mahasiswa Program Studi Magister Ilmu Kelautan Pascasarjana Universitas Pattimura \\ *laura.siahainenia@gmail.com, makatitamiftahul@gmail.com \\ Corresponding author*
}

\begin{abstract}
ABSTRAK: Kepiting bakau telah menjadi komoditas penting di Indonesia yang hidup di ekosistem mangrove. Penelitian ini bertujuan untuk 1) menganalisis kondisi lingkungan ekosistem mangrove Passo yang menjadi habitat alami kepiting bakau; 2) menganalisis komposisi jenis, kepadatan, rasio kelamin, status reproduksi, (ukuran, waktu dan lokasi reproduksi kepiting bakau; dan 3) merumuskan strategi pengelolaan sumberdaya kepiting bakau (Scylla spp.) serta habitatnya. Penelitian berlangsung di ekosistem mangrove Passo Teluk Ambon sejak Agustus 2015-Januari 2016. Pengumpulan data bioekologi kepiting bakau menggunakan metode purposive sampling, sedangkan strategi pengelolaan diperoleh melalui hasil wawancara terstruktur dengan masyarakat. Hasil penelitian menunjukkan kualitas lingkungan masih baik untuk pertumbuhan dan kelangsungan hidup kepiting bakau. Ditemukan empat jenis kepiting bakau dengan tingkat kepadatan yang sangat rendah. Rasio kelamin bergeser dari 1:1. Hampir semua individu yang tertangkap tergolong dalam fase reproduksi dengan ukuran lebar karapaks $10-15 \mathrm{~cm}$. Puncak musim reproduksi pada bulan Januari di sepanjang alur pasang surut, zona depan hutan mangrove hingga zona laut. Terdapat sepuluh strategi pengelolaan yang direkomendasikan terkait keberlanjutan populasi kepiting bakau dan kelestarian habitat.
\end{abstract}

Kata kunci: Kepiting bakau, Scylla, ekosistem mangrove, pengelolaan, kepadatan

ABTSRACT: Mud crabs have become an important commodity in Indonesia. The purpose of the research was to 1) analyze environmental conditions of the mud crabs habitat; 2) analyze the species compositions, sex ratio, reproduction status (size, period, and the reproduction site) of the mud crab; and 3) formulate management strategies for mud crabs (Scylla spp.) as well as their habitats. This Research was carried out in Passo mangrove ecosystem from August 2015-January 2016. Purposive sampling techniques was used to collect bio-ecological data of mud crabs whereas a structured interview was applied to obtain a management strategy data. The resust showed that the quality of Passo mangrove ecosystem is in good condition for the growth and survival of mud crabs. Four types of mud crabs were found with very low density. Sex ratio shifted from 1:1. Almost all individuals caught were in the reproductive phase with a carapace width of $10-15 \mathrm{~cm}$. The peak of the reproductive season in January along the tidal channel, the mangrove forest front zone to the sea zone. This study recommend ten strategies in relation to the sustainability of the mangrove crab population and habitat preservation.

Keywords: Mud crabs, Scylla, mangrove ecosystem, management, density 


\section{PENDAHULUAN}

Ekosistem hutan mangrove merupakan salah satu ekosistem pesisir penting (Karimah, 2017; Baderan, dkk., 2018) yang sangat potensial mendukung kehidupan keanekaragaman flora dan fauna. Fungsi ekosistem mangrove baik secara ekologis yaitu tempat mencari makan, berlindung, memijah, maupun secara ekonomis bermanfaat bagi masyarakat sebagai pengguna sumberdaya (Poedjirahajoe \& Matatula, 2019). Khususnya manfaat ekonomi yang telah dirasakan masyarakat hingga saat ini dengan memanfaatkan sumberdaya seperti kerang, ikan dan lainnya baik untuk konsumsi sehari-hari maupun untuk dijual (Agungguratno \& Darwanto, 2016; Takarendehang, $d k k$., 2018).

Salah satu komoditas perikanan penting yang terdapat di ekosistem mangrove yaitu kepiting bakau (Scylla spp.) (Chadijah, dkk., 2013; Tahmid, dkk., 2015). Kepiting bakau telah menjadi komoditas perikanan penting di Indonesia sejak awal tahun 1980-an. Perikanan kepiting bakau di Indonesia diperoleh dari penangkapan stok alam di perairan pesisir, khususnya di area mangrove atau estuaria dan dari hasil budidaya di tambak air payau. Kepiting bakau memiliki harga jual yang tinggi, disenangi oleh masyarakat karena kandungan gizi yang tinggi sehingga menyebabkan eksploitasi terhadap sumberdaya ini juga tinggi.

Ekosistem mangrove Passo Teluk Ambon merupakan ekosistem mangrove terbesar di Pulau Ambon. Letak ekosistem ini sangat dekat dengan pemukiman penduduk sehingga berbagai aktivitas masyarakat berdampak pada kelangsungan sumberdaya ekosistem mangrove tersebut, salah satunya keberadaan kepiting bakau. Saat ini, populasi kepiting bakau di ekosistem mangrove Passo telah mengalami penurunan kualitas maupun kuantitas akibat tekanan eksploitasi (Syam, et al, 2011) dan tekanan ekologis habitat (Siahainenia, 2010). Eksploitasi kepiting bakau berlangsung tanpa memperhitungkan waktu reproduksi, ukuran reproduksi, dan lokasi reproduksi. Sementara di sisi lain ekosistem mangrove Passo sebagai habitat alami utama kepiting bakau, telah mengalami degradasi akibat berbagai tekanan ekologis seperti fragmentasi, pemanfaatan lahan dan sedimentasi (Siahainenia, $d k k$., 2014) sebagai dampak kegiatan pembangunan. Perubahan luasan hutan mangrove Desa Passo di tahun 2009-2014 yaitu sebesar 5,71 ha atau sekitar 19,65\% (Madiama, $d k k$., 2016). Hal tersebut tentunya memberikan dampak negatif terhadap keberadaan sumberdaya pada ekosistem mangrove Desa Passo. Jika hutan mangrove sebagai habitat kepiting bakau mengalami perubahan atau degradasi maka keberadaan kepiting bakau juga tentunya dapat mengalami penurunan. Status ekosistem mangrove Desa Passo termasuk kawasan lindung berdasarkan Rencana Umum Tata Ruang Kota Ambon 2011-2031. Suatu kawasan lindung tentunya menjadi habitat yang baik bagi oragnisme yang hidup di dalamnya. Penurunan populasi kepiting bakau yang terjadi terus menerus mengindikasikan bahwa kondisi ekosistem mangrove Desa Passo sudah tidak menjadi habitat yang baik bagi habitat kepiting bakau (Scylla spp.) di kawasan tersebut.

Kelestarian dan keberlangsungan hidup kepiting bakau perlu dijaga, untuk itu diperlukan strategi pengelolan yang tepat. Dengan demikian penelitian untuk mengkaji aspek ekobiologi sebagai data dan informasi dasar dalam menyusun strategi pengelolaan sumberdaya kepiting bakau pada ekosistem mangrove Desa Passo sangat perlu dilakukan untuk menjamin kelestarian sumberdaya kepiting bakau secara khusus dan habitat alami secara umum. Penelitian ini bertujuan untuk 1) menganalisis kondisi lingkungan ekosistem mangrove Passo yang menjadi habitat alami kepiting bakau; 2) menganalisis komposisi jenis, kepadatan, rasio kelamin, status reproduksi (ukuran reproduksi, waktu reproduksi dan lokasi reproduksi) kepiting bakau eksisting pada ekosistem mangrove Passo; dan 3) merumuskan strategi pengelolaan sumberdaya kepiting bakau (Scylla spp.) serta habitatnya. 


\section{METODE PENELITIAN}

Penelitian ini dilakukan bulan Agustus 2015-Januari 2016, berlokasi pada ekosistem mangrove Passo Kecamatan Teluk Ambon Baguala, Kota Ambon dengan pengamatan pada empat substasiun dengan karakteristik yang berbeda. Data suhu dan salinitas diukur tiap substasiun pengamatan secara insitu selama fase bulan dalam periode penelitian. Sampel substrat diambil pada tiap substasiun dengan bantuan sediment core selanjutnya diayak dan diklasifikasikan menurut skala wenworth. Data mangrove dikumpulkan dengan metode transek liniear kuadrat. Penangkapan kepiting bakau menggunakan bubu pada zona hutan mangrove (zona belakang dan tengah) dan jaring pada zona laut, selama sehari semalam pada tiap stasiun penelitian secara acak. Wawancara terstruktur dengan masyarakat (responden), termasuk nelayan kepiting bakau dilakukan untuk mengetahui aktifitas masyarakat, aktifitas nelayan kepiting bakau, kondisi sosial ekonomi dan kelembagaan masyarakat. Jumlah sampel responden ditentukan secara random proporsional berlapis (Stratified Proporsional Random Sampling).

\section{Metode Analisis Data}

Persentasi partikel sedimen dianalisis melalui formula:

Persentasi partikel sedimen (\%) = $\frac{\text { Berat tiap ukuran butiran sedimen ( gram) }}{\text { Berat total populasi sedimen ( gram ) }} \times 100 \%$

Analisis kerapatan vegetasi mangrove yang meliputi kerapatan $(\mathrm{K})$ dan kerapatan relatif (KR) menurut formula:

$\mathrm{KR}=\frac{\sum \text { individu satu jenis }}{\text { Luas petak contoh }}$

$\mathrm{KR}=\frac{\text { Kerapatan satu jenis }}{\text { Kerapatan semua jenis }} \times 100 \%$

Identifikasi jenis kepiting bakau hasil tangkapan menggunakan pedoman identifikasi menurut Keenan, et al. (1998). Analisis kepadatan dilakukan dengan cara menghitung jumlah individu kepiting bakau yang ditemukan di setiap substasiun penelitian menggunakan formula:

$$
D=\frac{N i}{A}
$$

Ket:

$\mathrm{D}=$ Kepadatan jenis ke-i (ind $\left./ 100 \mathrm{~m}^{2}\right)$

$\mathrm{Ni}=$ Total individu jenis ke-i yang ditemukan

$\mathrm{A}=$ Luas area pengambilan $\left(100 \mathrm{~m}^{2}\right)$

Analisis kepadatan dilakukan terhadap total kepiting bakau yang tertangkap menurut jenis dan jenis kelamin, sedangkan analisis rasio kelamin kepiting bakau ditentukan dengan melihat perbandingan frekuensi individu jantan dan betina menggunakan formula:

$$
R=\frac{n j}{n b}
$$

Ket:

$\mathrm{R}=$ rasio kelamin

$\mathrm{nj}=$ jumlah jantan (ind.)

$\mathrm{nb}=$ jumlah beetina (ind.)

Analisis status reproduksi kepiting bakau dilakukan dengan cara mengidentifikasi tingkat kematangan gonad dari kepiting bakau betina yang tertangkap dengan berpedoman pada Siahainenia (2008). Selanjutnya data jumlah individu kategori matang gonad dan tidak matang gonad diplot dalam diagram menurut bulan pengamatan. Data ukuran lebar karapaks yang diperoleh selanjutnya dianalisis frekuensinya. Jumlah individu dari tiap frekuensi ukuran diplot menurut bulan pengamatan dalam bentuk diagram. Analisis waktu dan lokasi reproduksi kepiting bakau pada ekosistem mangrove Passo dan Waiheru, digunakan Coresspondence Analysis (CA) untuk menganalisis distribusi individu betina pada tiap tingkat kematangan gonad terhadap bulan pengamatan dan distribusi individu betina tiap tingkat kematangan gonad pada zona depan (laut), zona tengah dan zona belakang hutan mangrove. Rumusan strategi pengelolaan sumberdaya kepiting bakau (Scylla spp.) di ekosistem mangrove Desa Passo dan Waiheru dilakukan melalui pendekatan metode analisis 
SWOT yang meliputi lingkungan internal dan eksternal mengikuti Rangkuti (2001).

\section{HASIL DAN PEMBAHASAN}

\section{Kondisi Kualitas Lingkungan}

Ekosistem mangrove Passo merupakan bagian dari perairan Teluk Ambon Dalam pada posisi 03'37'40" LS-03³9'50" LS dan $128^{\circ} 11^{\prime} 29^{\prime \prime}$ BT-128 19'25" LS. Berdasarkan hasil penelitian, suhu pada keempat substasiun berkisar antara $27-28^{\circ} \mathrm{C}$ (Tabel 1). Suhu maksimal yang dapat ditolerir kepiting bakau adalah sekitar $42,1^{\circ} \mathrm{C}$, karena pada nilai suhu tersebut, pertumbuhan kepiting bakau menurun. Sebaliknya suhu minimal yang mulai mengganggu pertumbuhan kepiting bakau adalah sekitar $20^{\circ} \mathrm{C}$. Hasil penelitian Hastuti, dkk (2019) menunjukkan hasil perlakuan suhu $\left(25^{\circ} \mathrm{C}, \quad 27^{\circ} \mathrm{C}, \quad 29^{\circ} \mathrm{C}\right.$ dan $\left.31^{\circ} \mathrm{C}\right)$ untuk pertumbuhan dan kelangsungan hidup benih kepiting bakau diperoleh suhu terbaik adalah $29^{\circ} \mathrm{C}$. Kualitas lingkungan adalah faktor penting yang dapat mempengaruhi keberadaan dan pertumbuhan semua organisme termasuk kepiting bakau. Kepiting bakau hanya akan menempati bagian-bagian perairan yang memiliki kondisi kualitas lingkungan yang disukai (preferensi) dan mampu ditolerir olehnya (Siahainenia, 2008).

Nilai salinitas yang diperoleh pada penelitian ini berkisar antara 10-28 ppm. Soim (1999) menyatakan bahwa kadar garam yang dapat memberikan produksi tinggi berkisar antara 15-30 ppm. Menurut Muskar (2007), lokasi hidup kepiting bakau yang baik adalah pada perairan bersalinitas antara 15-30 ppm. Jenis Scylla serrata dapat mentolerir kisaran salinitas yang besar yaitu 2-40 ppt (La Sara, et al., 2006; Saputri \& Muanmmar, 2018)
Substrat mangrove sangat mendukung kehidupan kepiting bakau, terutama untuk melangsungkan perkawinan. Tekstur substrat dasar yang baik bagi kepiting bakau untuk kelangsungan hidupnya terdiri dari substrat sangat halus seperti lempung berdebu. Selain itu tekstur yang sedang juga disukai, namun kepiting bakau tidak menyukai substrat yang kasar. Hasil analisis struktur substrat berdasarkan skala wentworth menggambarkan secara umum substrat dasar di ekosistem mangrove Passo berupa jenis kerikil (granule), pasir sedang (medium sand), dan pasir halus (find sand). Semua substasiun didominasi oleh pasir halus $(39,21-72,19 \%)$.

\section{Komposisi Jenis dan Kerapatan Vegetasi Mangrove}

Ketebalan hutan mangrove di daerah Passo dan sekitarnya mencapai $200 \mathrm{~m}$ dari garis pantai (Suyadi, 2009). Berdasarkan hasil penelitian ditemukan 16 spesies mangrove yang berada di kawasan ekosistem mangrove Passo (Tabel 2). Kerapatan dan kerapatan relatif tiap jenis mangrove dari tiap kategori pohon, sapihan maupun anakan adalah $\mathrm{K}=0,005-2,50$ ind $/ \mathrm{m}^{2}$ dan $\mathrm{KR}=2,44-43,9 \%$ (substasiun 1 ); $\mathrm{K}=0,015-3,50$ ind $/ \mathrm{m}^{2}$ dan $\mathrm{KR}=2,00-53,85 \%$ (substasiun 2); $\mathrm{K}=0,02-2,50 \mathrm{ind} / \mathrm{m}^{2}$ dan $\mathrm{KR}=$ $3,75-85,71 \%$ (substasiun 3) dan $\mathrm{K}=0,05-1,00$ ind $/ \mathrm{m}^{2}$ dan $\mathrm{KR}=33,3-100,0 \%$ (substasiun 4 ).

\section{Komposisi Jenis dan Kepadatan Kepiting Bakau (Scylla spp.) \\ Hasil identifikasi jenis kepiting bakau hasil tangkapan nelayan yang dikoleksi selama penelitian berlangsung menunjukan bahwa pada ekosistem mangrove Passo dijumpai empat jenis yaitu: Scylla serrata, $S$. tranqubarica, $S$. paramamosain dan S. olivacea.}

Tabel 1. Kualitas lingkungan ekosistem mangrove Desa Waiheru

\begin{tabular}{cccc}
\hline Substasiun & $\begin{array}{c}\text { Suhu } \\
\left({ }^{\circ} \mathrm{C}\right)\end{array}$ & $\begin{array}{c}\text { Salinitas } \\
(\mathrm{ppm})\end{array}$ & $\begin{array}{c}\text { Struktur Substrat } \\
\text { Dominan }\end{array}$ \\
\hline 1 & 28 & 28 & Pasir halus \\
2 & 28 & 24 & Pasir halus \\
3 & 28 & 24 & Pasir halus \\
4 & 27 & 10 & Pasir halus \\
\hline
\end{tabular}


Tabel 2. Komposisi jenis dan jumlah individu mangrove di ekosistem mangrove Desa Passo

\begin{tabular}{clcl}
\hline No & \multicolumn{1}{c}{ Jenis Mangrove } & No & \multicolumn{1}{c}{ Jenis Mangrove } \\
\hline 1 & Aegiceras corniculatum & 9 & Acrostichum aureum \\
2 & Avicennia alba & 10 & Excoecaria agallocha \\
3 & Bruguiera cylindrica & 11 & Ceriops tagal \\
4 & Heritiera littoralis & 12 & Bruguiera gymnorhiza \\
5 & Rhizophora mucronata & 13 & Bruguieraparviflora \\
6 & Sonneratia alba & 14 & Scyphiphora hydrophyllaceae \\
7 & Nypa fruticans & 15 & Rhizophora apiculata \\
8 & Acanthus ilicifolius & 16 & Camptostemon scultchii \\
\hline
\end{tabular}

Nilai kepadatan rata-rata kepiting bakau pada ekosistem mangrove Passo adalah 0,46 ind $/ 100 \mathrm{~m}^{2}$. Nilai ini lebih rendah dibandingkan hasil penelitian beberapa tahun sebelumnya pada lokasi yang sama maupun pada ekosistem mangrove lain di Maluku (Siahainenia 2000). Nilai kepadatan rata-rata jenis Scylla olivacea paling tinggi dibandingkan jenis lainnya (Tabel 3). Jika dibandingkan dengan hasil penelitian Siahainenia (2010), maka nilai kepadatan ratarata dari tiap jenis di ekosistem mangrove Desa Passo relatif lebih rendah. Hal ini mengindikasikan terjadi penurunan potensi sumberdaya kepiting bakau. Nilai kepadatan rata-rata kepiting bakau menurut jenis kelamin berkisar antara 0,01-018 ind $/ 100 \mathrm{~m}^{2}$ untuk individu jantan dan 0,01-0,07 ind $/ 100 \mathrm{~m}^{2}$ untuk indiviu betina (Tabel 4).

\section{Rasio Kelamin}

Hasil analisis rasio kelamin kepiting bakau pada ekosistem mangrove Passo memperlihatkan pergeseran dari rasio ideal 1:1 yang berarti populasi jantan dan betina tidak seimbang. Ketidakseimbangan jenis kelamin ini dapat disebabkan karena adanya fenomena migrasi biologi untuk tujuan reproduksi yang dilakukan oleh kepiting bakau betina, atau akibat penurunan kualitas lingkungan yang cukup ekstrim. Pendapat ini didukung oleh Wenner (1989) yang menyatakan bahwa perubahan rasio kelamin dari 1:1 pada kepiting biru (Calinnectes sapidus), menunjukan adanya perbedaan pola migrasi antara jantan dan betina, atau akibat mortalitas alami.

Tabel 3. Nilai kepadatan rata-rata kepiting bakau menurut jenis pada ekosistem mangrove Passo

\begin{tabular}{cccc}
\hline \multicolumn{4}{c}{ Nilai Kepadatan Rata-rata $\left(\mathbf{i n d} / \mathbf{1 0 0 \mathbf { m } ^ { 2 } )}\right.$} \\
\hline S. serrata & S. paramamosain & S. tranquebarica & S. olivacea \\
0.13 & 0.03 & 0.05 & 0.25 \\
$0,86^{*}$ & $0,78^{*}$ & $0,60^{*}$ & $0,77^{*}$ \\
\hline Ket: * Siahanenia $(2010)$ & &
\end{tabular}

Tabel 4. Nilai kepadatan rata-rata kepiting bakau (Scylla spp.) menurut jenis Kelamin

\begin{tabular}{cccccccc}
\hline \multicolumn{8}{c}{ Nilai Kepadatan Rata-rata (ind/100 $\mathbf{m}^{\mathbf{2}}$ ) } \\
\hline \multicolumn{1}{c}{ S. serrata } & \multicolumn{2}{c}{ S.paramamosain } & S. tranquebarica & \multicolumn{2}{c}{ S olivacea } \\
\hline$J$ & $B$ & $J$ & $B$ & $J$ & $B$ & $J$ & $B$ \\
0.08 & 0.05 & 0.01 & 0.02 & 0.04 & 0.01 & 0.18 & 0.07 \\
$0,54^{*}$ & $0,31^{*}$ & $0,36^{*}$ & $0,31^{*}$ & $0,33^{*}$ & $0,20^{*}$ & $0,47^{*}$ & $0,14^{*}$ \\
\hline Ket: * Siahanenia (2010) & & & & & & &
\end{tabular}




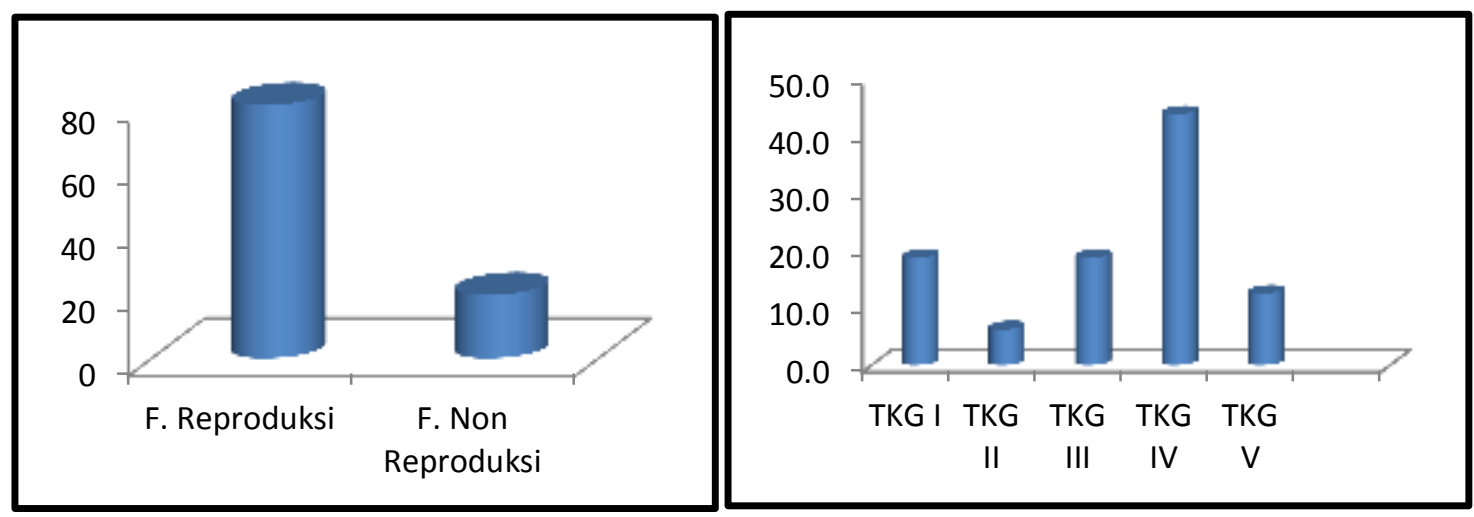

Gambar 2. Status reproduksi kepiting bakau betina pada ekosistem mangrove Passo

\section{Status Reproduksi Kepiting Bakau}

Kepiting bakau hasil tangkapan nelayan di ekosistem mangrove Passo terdiri atas lima tingkat perkembangan gonad (TKG I-V), yang menunjukan daya dukung ekosistem mangrove Passo terhadap proses reproduksi kepiting bakau. Selama periode penelitian individu kepiting bakau betina yang tertangkap memiliki fase reproduksi (TKG I-V) (80\%) dan fase nonreproduksi (20\%) (Gambar 2).

Dalam penelitian ini ditemukan individu betina dalam TKG V (salin), walaupun dalam jumlah sangat sedikit (12,5\%), yang merupakan hasil tangkapan jaring pada zona laut. Dalam operasi penangkapan dengan alat tangkap bubu tidak ditemukan individu betina TKG V. Kondisi ini membuktikan fenomena migrasi reproduksi oleh kepiting bakau betina saat akan memijah. Kanna (2002) menyatakan bahwa dalam siklus hidupnya, kepiting bakau (Scylla spp.) betina akan berusaha mencari perairan yang kondisinya cocok sebagai tempat melakukan proses pemijahan, khususnya terhadap parameter suhu dan salinitas air laut. Senada dengan itu, Hill (1974) dan Le Reste, et al. (1976) menyatakan bahwa kepiting bakau melangsungkan perkawinan di perairan hutan mangrove dan seiring dengan perkembangan gonadnya, kepiting bakau betina akan bermigrasi ke laut untuk memijah.

\section{Ukuran Reproduksi Kepiting Bakau}

Sebagian besar kepiting bakau (Scylla spp.) yang tertangkap selama periode Agustus 2015-Januari 2016 berada dalam kelompok ukuran sedang $(10-15 \mathrm{~cm})$ dan kelompok ukuran kecil $(<10 \mathrm{~cm})$ (Gambar 3). Sementara hanya sedikit dan bahkan hampir tidak ditemukan dalam ukuran besar $(>15 \mathrm{~cm})$. Hasil analisis tingkat kematangan gonad memperlihatkan bahwa pada kedua kelompok ukuran tersebut (sedang dan kecil), kepiting bakau (Scylla spp.) betina berada dalam fase reproduksi (TKG I, TKG II, TKG III, dan TKG IV). Kondisi tersebut mengindikasikan bahwa nelayan kepiting bakau cenderung menangkap kepiting dengan semua ukuran (kecil, sedang, dan besar). Ditemukannya kepiting bakau dalam fase reproduksi dengan ukuran sedang dan kecil mengindikasikan telah terjadi penurunan ukuran kepiting bakau, akibat penangkapan berlebih dan degradasi ekosistem mangrove Passo.

\section{Waktu Reproduksi Kepiting Bakau}

Analisa Correspondent Analysis (CA) yang digunakan untuk mengkaji distribusi temporal individu betina dari tiap tingkat kematangan gonad pada ekosistem mangrove Passo dapat dilihat pada Gambar 4a. Menurut Siahainenia (2010), fase bulan, saat kepiting bakau dengan tingkat kematangan gonad akhir atau TKG IV (matang sempurna) dan TKG V (salin) ditemukan dalam jumlah individu tertinggi, maka dapat diindikasikan sebagai puncak musim reproduksi. Dengan demikian dapat dikatakan bahwa periode Agustus 2015Desember 2016 bukan merupakan puncak musim reproduksi kepiting bakau pada ekosistem mangrove Desa Passo. 


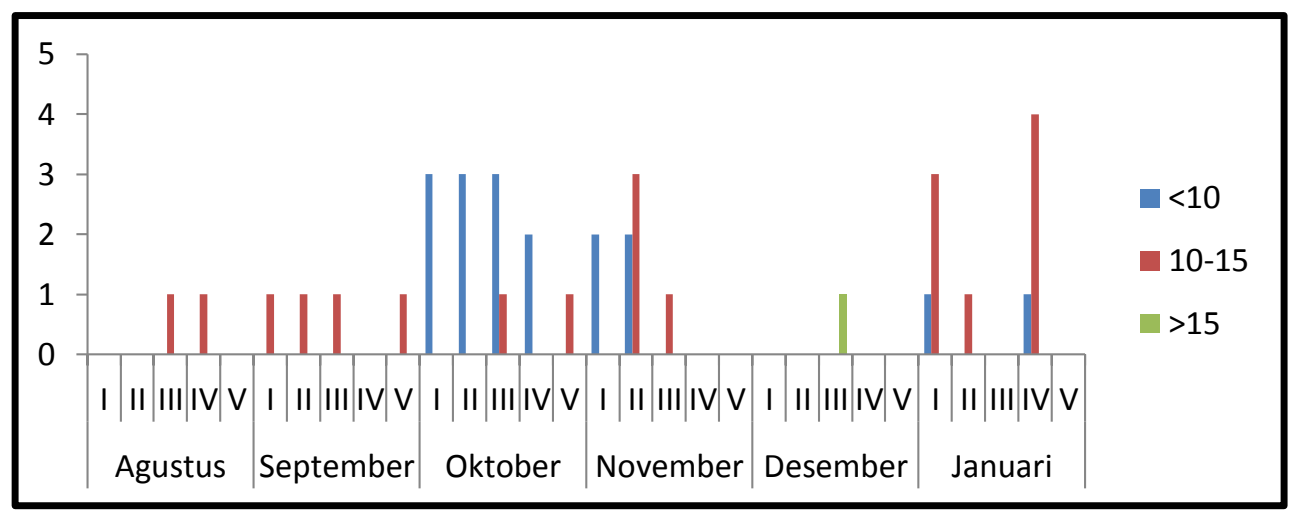

Gambar 3. Ukuran reproduksi kepiting bakau (Scylla spp.) pada ekosistem mangrove Passo

Pada periode Mei-Agustus terjadi peningkatan jumlah individu kepiting bakau betina matang gonad tingkat akhir (TKG IV dan V) (Siahainenia, 2010), sehingga ditetapkan sebagai puncak musim reproduksi kepiting bakau pada wilayah ekosistem mangrove Passo. Dikatakan juga puncak musim reproduksi pada wilayah tersebut berlangsung selama kurang lebih empat bulan. Meskipun demikian, dengan ditemukannya individu kepiting bakau betina TKG $\mathrm{V}$ atau pasca memijah pada bulan September dan awal Oktober dapat memperkuat pendapat tersebut. Siahainenia (2010) juga menyatakan bahwa masa pemijahan berkaitan dengan kesesuaian kondisi lingkungan perairan dalam mendukung proses pemijahan sehingga ada kemungkinan terjadi perubahan masa puncak pemijahan setiap tahun pada suatu wilayah perairan, yakni dapat berlangsung lebih panjang atau lebih pendek tergantung pada kondisi lingkungan perairan dan kondisi musim.

\section{Lokasi Reproduksi Kepiting Bakau}

Hasil analisa Correspondent Analysis (CA) untuk mengkaji distribusi spasial individu betina dari tiap tingkat kematangan gonad pada ekosistem mangrove Passo dapat dilihat pada Gambar 4b. Pada gambar tersebut menunjukkan bahwa kepiting bakau betina TKG I, II dan III memiliki preferensi pada zona tengah dan belakang hutan mangrove, sedangkan individu dengan TKG IV dan V memiliki preferensi pada zona depan hutan mangrove. Kepiting bakau betina matang gonad akan melakukan migrasi spesifik yakni bergerak dari perairan hutan mangrove dan muara sungai ke perairan laut untuk memenuhi kebutuhan reproduksinya, sehingga pada TKG V (salin) kepiting bakau betina ditemukan pada perairan laut.

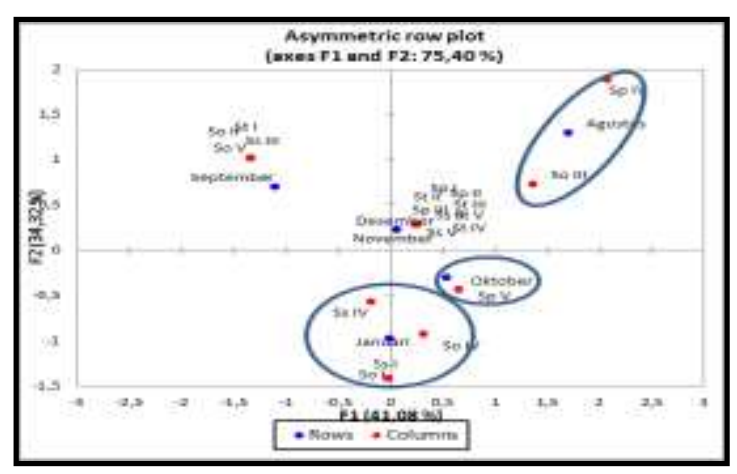

(a)

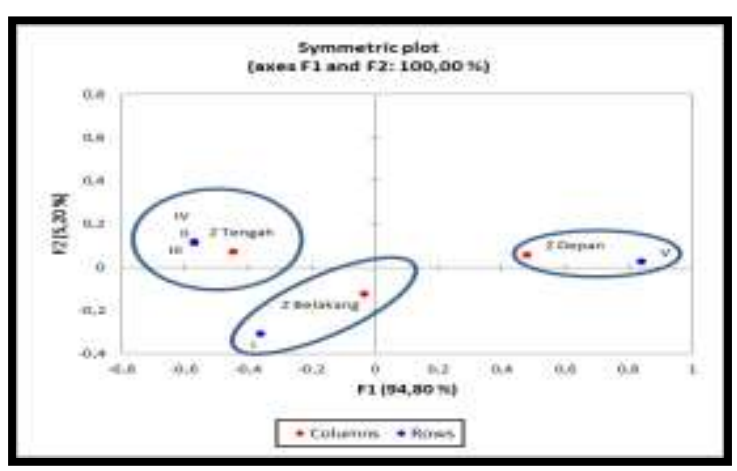

(b)

Gambar 4. Hasil analisis CA distribusi temporal (a) dan spasial (b) kepiting bakau betina dalam tiap tingkat kematangan gonad 


\section{Strategi Pengelolaan Kepiting Bakau}

Berdasarkan hasil analisa menggunakan SWOT (Tabel 5) diperoleh 4 strategi SO, 4 strategi WO, 1 strategi ST dan 1 strategi WT.

1. Budidaya kepiting bakau, strategi ini dibuat untuk menjamin ketersediaan sumberdaya kepiting bakau di alam, dan memenuhi kebutuhan pasar. Perlu kerjasama antar pihak terkait untuk membangun dan menyediakan sarana dan prasarana yang dibutuhkan.

2. Pengelolaan ekosistem mangrove Desa Passo, pengelolaan ekosistem mangrove Desa Passo diharapkan dapat mengurangi ancaman pemanfaatan yang merusak sehingga berdampak terhadap keberlangsungan hidup kepiting bakau. Kegiatan pengelolaan diantaranya mengupayakan ekowisata maupun hutan lindung.

3. Pengaturan waktu tangkap, alat tangkap dan lokasi tangkap, merupakan upaya untuk menjamin ketersediaan sumberdaya kepiting bakau di alam. Upaya yang dapat dilakukan yaitu mempertimbangkan close seasson dan close area (pada jalur reproduksi) saat puncak musim reproduksi. Alat tangkap yang digunakan sebaiknya alat tangkap yang ramah lingkungan seperti bubu dan jaring dengan ukuran mata yang besar.

4. Peraturan Negeri tentang pengelolaan sumberdaya kepiting bakau dan ekosistem mangrove sebagai habitatnya, upaya yang harus dilakukan yaitu membuat aturan-aturan yang mengikat berupa Peraturan Negeri.

5. Advokasi nelayan tentang aspek biologi reproduksi kepiting bakau, strategi ini dibuat karena pada umumnya nelayan kepiting bakau dalam melakukan penangkapan kepiting bakau tidak memiliki pengetahuan tentang ciri kepiting bakau fase reproduksi. Upaya yang perlu dilakukan yaitu pemberdayaan masyarakat tentang aspek bioreproduksi kepiting bakau.

6. Ukuran kepiting bakau yang boleh ditangkap. Upaya yang harus dilakukan yaitu penegakan aturan tentang ukuran kepiting bakau yang boleh ditangkap.

7. Rehabilitasi dan konservasi ekosistem mangrove Desa Passo, strategi ini dibuat
DOI: https://doi.org/10.30598/TRITONvol16issue1page8-18

mengingat tingkat degradasi ekosistem mangrove Passo cukup tinggi. Upaya rehabilitasi dengan melakukan penanaman individu baru sementara upaya konservasi berupa perlindungan ekosistem mangrove terhadap aktifitas pemanfaatan selama waktu tertentu.

8. Pemanfaatan sumberdaya kepiting bakau secara berkelanjutan, dalam melakukan aktifitas pemanfaatan sumberdaya kepiting bakau dilakukan dengan cara-cara yang ramah lingkungan sehingga ketersediaan kepiting bakau di alam tetap terjaga dan lestari.

9. Melakukan kegiatan penyadaran masyarakat, upaya untuk meningkatkan kesadaran masyarakat akan pentingnya melestarikan lingkungan dilakukan dengan cara, sosialisasi dan penyuluhan untuk menjaga dan melestarikan sumberdaya hutan mangrove dengan membuang sampah pada tempatnya.

10. Peran aktif Pemerintah Negeri Passo terkait pengelolaan ekosistem mangrove dan sumberdaya kepiting bakau, strategi ini dibuat karena dalam membuat peraturan atau regulasi dalam upaya pengelolaan kepiting bakau dan ekosistem mangrove perlu adanya peran aktif Pemerintah.

\section{KESIMPULAN}

Berdasarkan uraian yang telah dikemukakan maka dapat disimpulkan sebagai berikut:

1. Kondisi kualitas lingkungan pada ekosistem mangrove Desa Passo sangat baik bagi pertumbuhan dan kelangsungan hidup kepiting bakau

2. Telah ditemukan empat jenis kepiting bakau dengan nilai kepdatan rata-rata adalah 0,46 ind $/ 100 \mathrm{~m}^{2}$. Rasio kelamin mengalami pergeseran dari rasio ideal 1:1. Individu kepiting bakau betina yang tertangkap memiliki fase reproduksi (TKG I-V) $(80 \%)$ dan fase non-reproduksi (20\%), dengan ukuran reproduksi pada kelompok ukuran sedang dan kecil. Waktu reproduksi 
berlangsung Agustus-Januari dengan puncak pada Januari di alur pasang surut. Lokasi reproduksi kepiting bakau betina TKG I, II dan III memiliki preferensi pada zona tengah dan belakang hutan mangrove, sedangkan individu dengan TKG IV dan V memiliki preferensi pada zona depan mangrove.

3. Terdapat 10 strategi pengelolaan kepiting bakau di ekosistem mangrove Desa Passo.

Tabel 5. Matriks SWOT pengelolaan kepiting bakau di ekosistem mangrove Desa Passo

\begin{tabular}{|c|c|c|}
\hline & Strength (S) & Weakness $(\mathrm{W})$ \\
\hline Eksternal & $\begin{array}{l}\text { 1. Potensi reproduksi kepiting bakau. } \\
\text { 2. Ditemukannya } 4 \text { jenis kepiting } \\
\text { bakau. } \\
\text { 3. Ekosistem Desa Passo sangat luas } \\
\text { dibandingkan dengan ekosistem } \\
\text { mangrove lain yang ada di Kota } \\
\text { Ambon, sehingga bisa menjadi } \\
\text { habitat yang baik bagi kepiting } \\
\text { bakau (Scylla spp). } \\
\text { Kepiting bakau (Scylla spp) } \\
\text { memiliki nilai jual di pasaran yang } \\
\text { baik dari waktu ke waktu } \\
\text { Akses ke pasar sangat dekat, } \\
\text { sehingga tidak sulit untuk } \\
\text { transportasi }\end{array}$ & 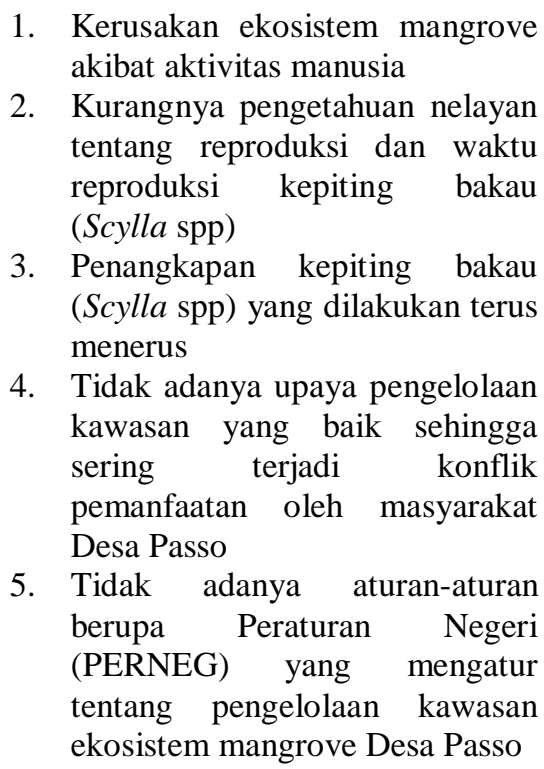 \\
\hline Opportunities (O) & Strategi S-O & Strategi W-O \\
\hline $\begin{array}{l}\text { 1. Potensi budidaya } \\
\text { 2. Akses pasar untuk skala lokal } \\
\text { sampai skala ekspor } \\
\text { 3. Dukungan Pemerintah Negeri } \\
\text { Passo dalam upaya pengelolaan } \\
\text { sumberdaya kepiting bakau } \\
\text { (Scylla } \text { spp) }\end{array}$ & $\begin{array}{l}\text { 1. Pengaturan waktu tangkap, lokasi } \\
\text { tangkap } \\
\text { 2. Budidaya kepiting bakau } \\
\text { 3. Pengelolaan ekosistem mangrove } \\
\text { Desa Passo } \\
\text { 4. Peraturan Negeri tentang } \\
\text { pengelolaan sumberdaya kepiting } \\
\text { bakau dan ekosistem mangrove } \\
\text { sebagai habitatnya }\end{array}$ & $\begin{array}{l}\text { 1. Memberikan pengetahuan kepada } \\
\text { nelayan tentang reproduksi } \\
\text { kepiting bakau } \\
\text { 2. Ukuran kepiting bakau yang } \\
\text { boleh ditangkap } \\
\text { 3. Rehabilitasi dan konservasi } \\
\text { ekosistem mangrove } \\
\text { 4. Pemanfaatan sumberdaya kepiting } \\
\text { bakau secara berkelanjutan }\end{array}$ \\
\hline Threat (T) & Strategi S-T & Strategi W-T \\
\hline $\begin{array}{l}\text { 1. Semakin berkurang berkurang } \\
\text { populasi (kualitas dan kuantitas) } \\
\text { sumberdaya kepiting bakau dari } \\
\text { waktu ke waktu apabila tidak } \\
\text { adanya upaya pengelolaan } \\
\text { 2. Pencemaran lingkungan akibat } \\
\text { sedimentasi, dan sampah yang } \\
\text { dibuang langsung ke kawasan } \\
\text { ekosistem mangrove maupun } \\
\text { sampah yang terbawa arus } \\
\text { 3. Adanya aktifitas pembangunan } \\
\text { untuk pemukiman, maupun } \\
\text { perkantoran yang menyebabkan } \\
\text { kawasan ekosistem mangrove } \\
\text { yang menjadi habitat alami } \\
\text { kepiting bakau ditebang }\end{array}$ & $\begin{array}{l}\text { 1. Melakukan kegiatan penyadaran } \\
\text { masyarakat }\end{array}$ & $\begin{array}{l}\text { 1. Peran aktif Pemerintah Negeri } \\
\text { Passo terkait pengelolaan } \\
\text { ekosistem mangrove dan } \\
\text { sumberdaya kepiting bakau }\end{array}$ \\
\hline
\end{tabular}




\section{DAFTAR PUSTAKA}

Agungguratno \& Darwanto. 2016. Penguatan Eksoistem Mangrove untuk Pemberdayaan Ekonomi Masyarakat Pesisir. Eko-Regional 11(1): 1-9.

Baderan, D. W. K., R. Utina, N. Lapolo. 2018. Vegetation Structure, Species Diversity, and Mangrove Zonation Patterns in The Tanjung Panjang Nature Reserve Area, Gorontalo, Indonesia. International Journal of Applied Biology 2(2): 1-12. eISSN : 2580-2119.

Chadijah, A., Y. Wadritno, Sulistiono. 2013. Keterkaitan Mangrove, Kepiting Bakau (Scylla olivacea) dan Beberapa Parameter Kualitas Air di Perairan Pesisir Sinjai Timur. Octopus 1(2): 116-122.

Hastuti, Y. P., R. Affandi, R. Millaty, W. Nurussalam, S. Tridesianti. 2019. Suhu Terbaik untuk Meningkatkan Pertumbuhan dan Kelangsungan Hidup Benih Kepiting Bakau Scylla serrata di Sistem Resirkulasi. Jurnal Ilmu dan Teknologi Kelautan Tropis 11(2): 311-322. DOI: http://dx.doi.org/10.29244/ jitkt.v11i1.22727.

Hill BJ. 1974. Salinity and Temperature Tolerance of Zoea of The Portunid Crab Scylla serrata. Mar Bio, 25: 21-24

Kanna, I., 2002. Budidaya Kepiting Bakau. Penerbit Kanisius, Yogyakarta. 80 hal.

Karimah. 2017. Peran Ekosistem Hutan Mangrove Sebagai Habitat Untuk Organisme Laut. Jurnal Biologi Tropis 17(2): 51-58. eISSN:2549-7863.

Poedjirahajoe, E. \& J. Matatula. 2019. The Physiochemical Condition of Mangrove Ecosystems in The Coastal District of Sulamo, Kupang, East Nusa Tenggara, Indonesia. Jurnal Manajemen Hutan Tropika 25(3): 173-184. DOI: 10.7226/jtfm.25.3.173.

Keenan CP, Davie PJF, Mann DL. 1998. A Revision of The Genus Scylla De Haan, 1983 (Crustacea: Decapoda: Brachyura: Portunidae). The Raffles Bulletin Of Zoologi 46 (1): 217-245.

La Sara, J.A. Ingles, R.O. Aguilar, L.V. Laureta, R.B. Baldevarona, and S. Watanabe. 2006. Abundance and Distribution Patterns of Scylla spp. Larvae in the Lawele Bay, Southeast Sulawesi, Indonesia. Asian Fisheries Sciences, 19:331-347.

Le Reste L,Peno L, Rameloson A. 1976. Information on Biology of The Crab, Sylla serrata
DOI: https://doi.org/10.30598/TRITONvol16issue1page8-18

(Forskal) in Madagascar. Oceano. Bio. ORSTOM, Paris.

Muskar Y.F. 2007. Pedoman Teknis Budidaya Kepiting di Tambak. Fakultas Perikanan Universitas Hasanudin. Makasar.

Rangkuti F. 2001. Analisis SWOT Teknik Membedah Kasus Bisnis. PT Gramedia Pustaka Utama. Jakarta.

Saputri, M \& Muanmmar. 2018. Karakteristik Habitat Kepiting Bakau (Scylla sp.) di Ekosistem mangrove Silang Cadek Kecamatan Baitussalam Kabupaten Aceh Besar, Provinsi Aceh. Jurnal Biotik 6(1): 7580. ISSN: 2337-9812.

Setiawan, F. \& Triyanto. 2012. Studi Kesesuaian Lahan untuk Pengembangan Silvofishery Kepiting Bakau di Kabupaten Berau, Kalimantan Timur. Limnotek, 19(2):158-165.

Siahainenia L. 2000. Distribusi Kelimpahan Kepiting Bakau (Scylla serrata, S. oceanica dan S. Tranquebarica) dan Hubungan Dengan Karakteristik Habitat Pada Kawasan Hutan Mangrove Teluk Pelita Jaya, Seram Barat-Maluku. Thesis. Program Pascasarjana. IPB, Bogor.

Siahainenia L. 2008. Aspek Bioekologi Kepiting Bakau (Scylla spp.) Pada Ekosistem Mangrove Kabupaten Subang Jawa Barat. Disertasi. Sekolah Pascasarjana IPB. Bogor.

Siahainenia L. 2010. Kajian Potensi Reproduksi Dalam Upaya Pengelolaan Sumberdaya Kepiting Bakau (Scylla spp.) Pada Ekosistem Mangove Passo Teluk Ambon Dalam. Ambon. Laporan Penelitian. Fakultas Perikanan dan Ilmu Kelautan Universitas Pattimura.

Siahainenia, L., J. W. Tuahatu, N. Chr. Tuhumury, S. Ningkeula. 2014. Perubahan Warna Subtrat pada Daerah Hutan Mangrove Desa Passo. TRITON: Jurnal Manajemen Sumberdaya Perairan 10(2): 85-90.

Soim A. 1999. Pembesaran Kepiting. Cetakan Ketiga. Penebar Swadaya Jakarta.

Suyadi. 2009. Kondisi Hutan Mangrove di Teluk Ambon: Prospek dan Tantangan. Berita Biologi 9(5): 481-490.

Syam. A. R. et al. 2011. Laju Eksploitasi Kepiting Bakau (Scylla serrata) Di Perairan Mangrove Mayangan, Subang-Jawa Barat. Balai Riset Perikanan Laut, Muara Baru. Jakarta. Hal 201-207.

Tahmid, M., A. Fahrudin, Y. Wardiatno. 2015. Kualitas Habitat Kepiting Bakau (Scylla 
serrata) pada Ekosistem Mangrove Teluk Bintan, Kabupaten Bintan, Kepulauan Riau. Jurnal Ilmu dan Teknologi Kelautan Tropis 7(2): 535-551.

Takarendehang, R., C. F. A. Sondak, E. Kaligis, D. Kumampung, I. S. Manembu, U. N. W. J. Rembet. 2018. Kondisi Ekologi dan Nilai
Manfaat Hutan Mangrove di Desa Lansa, Kecamatan Wori, Kabupaten Minahasa Utara. Jurnal Pesisir dan Laut Tropis 2(1): 45-52.

Wenner, E.J. 1989. Incidence of Insemmination in Female Blue Crab Callinectes sapidus. J Crus Biol 9:587-594. 